\title{
Teaching students using technology: Facilitating success for students from low socioeconomic status backgrounds in Australian universities
}

\author{
Marcia Devlin \\ Federation University, Australia
}

\section{Jade McKay}

Deakin University, Australia

\begin{abstract}
Australian higher education has adopted a widening participation agenda with a focus on the participation of disadvantaged students, particularly those from low socioeconomic status (LSES) backgrounds. As these students begin to enter university in greater number and proportion than ever before, there is increasing interest in how best to facilitate their success. A recent national study employed semi-structured interviews to ask 89 successful LSES students what had helped them succeed. Twenty-six staff experienced in effectively teaching and supporting LSES students were also interviewed about what approaches they used in their work. Analysis of the study's findings indicates a strong theme related to the use of technology in effectively teaching and supporting LSES students. In particular, the use of a range of resources and media, facilitating interactive and connected learning, enabling personalised learning and assuring high academic standards were found to contribute to student success. The implications of these findings are discussed with a specific focus on promoting effective teaching practice and informing related policy. At a time when the diversity of the student cohort in Australian higher education institutions is increasing, the findings reported in this paper are both timely and critical for educators and institutions.
\end{abstract}

\section{Introduction}

Increasing numbers and proportions of so-called students from a wider range of backgrounds than has traditionally been the case are entering higher education in Australia as part of successive federal government agendas to widen participation, including students from low socioeconomic status (LSES) backgrounds. In such a context, questions about how to best teach and support increasingly diverse student cohorts effectively, inevitably arise (Northedge, 2002).

Diversification of the student body precipitates a need for institutions and educators to consider new approaches to teaching and learning (Dobbins, 2009; Northedge, 2002), particularly in light of research which suggests that traditional teaching and learning methods are not ideal when teaching so-called "nontraditional” students (Barrington, 2004; Roberts, 2011; Thomas, 2013; Toohey, 1999). Although a contested term, non-traditional is widely used and accepted in the literature and by policy makers, and encompasses those students underrepresented in higher education. With the number and proportion of students from low socioeconomic status (LSES) backgrounds rising in Australian higher education, the importance of ensuring that institutions and educators are adequately catering to a "student body diversified in aspects ranging from ... educational experience and preparedness, geographical location and external responsibilities” (Dobbins, 2009, p. 419), is highlighted. It is within the context of finding alternative and more innovative approaches to attending to the needs of non-traditional students that the role technology plays is of interest.

This paper reports on the findings from an Australian study (see Devlin, Kift, Nelson, Smith, \& McKay, 2012), which found a strong theme related to the use of technology in effectively teaching and supporting students from LSES backgrounds. After contextualising the issue and presenting the findings, the implications of these findings are discussed with a specific focus on promoting effective teaching practice and informing related institutional policy. The paper also contributes to scholarship at a timely juncture in the widening participation debate. 


\section{The changing higher education context}

As Devlin (2013b) notes, in the wider context in which higher education sits, the digital revolution is transforming almost every aspect of human existence. Drawing on Tanner (2011), she points out that "there have been significant, transformative and permanent changes in the nature of the business, delivery and presence of bookshops, newspapers, recorded music, movies, travel agents and department stores” (Devlin, 2013b, p. 2), to name but a few examples. Devlin (2013b) claims that universities are not exempt from such revolution. Universities teach, research, credential, engage, and socialise but there are alternative ways of doing these things that do not necessarily involve universities (Tanner, 2011). In this context, to ensure they remain relevant, universities must now rethink not only traditional teaching methods but also the fundamental nature of teaching and learning and the role of a university in the emerging and fast moving digital context (Devlin, 2013b).

As society is changing, so too are the characteristics and expectations of students. International research shows that students spend much of their free time on the Internet in myriad forms of learning and the exchange of information, including via social networking (Johnson et al., 2013). Modern students expect to use the Internet and other digital tools to undertake their university study. A study by Austrade (2012, p. 6) found that "students globally are demanding the use of technology to make classroom time more effective. As technology now enables on-demand access to information and interactive online experiences, learners are ... demanding on-demand and interactive learning experiences.” In their study of primary school students, Geer and Sweeney (2012) found that even at a young age, today's students have an expectation that they will use a variety of technologies in their learning and consider technology a "natural" tool in their everyday lives. Other studies have similarly pointed to a strong call from students for technology in their learning (Bennett, Maton, \& Kervin, 2008; Coaldrake, 2001; Condie, Munro, Seagraves, \& Kenesson, 2007; Cox et al., 2004; Davies \& Pittard, 2008; Jukes \& Dosaj, 2006; Prensky, 2005).

Students are often - although not always - very familiar and comfortable with a range of technologies. As Prensky (2001, 2005) and Palfrey and Gasser (2013) note, the monikers of "digital natives" and the "connected generation" are frequently employed to describe the learners of today. While these sorts of terms and concepts are contested, their widespread use points to a growing awareness of the ubiquity of technology in learning and teaching. Friedrich, Le Merle, Peterson, and Koster (2010) provide insight into this professed Generation $C$ - learners who are "connected, communicating, content-centric, computerized, community-oriented, always clicking” (p. 2). Where they exist, tertiary institutions can leverage the online skills learners have already developed outside of study by embracing online and blended learning models alongside traditional models in the provision of education.

University students come to campus less than in the past, partly because of their external responsibilities and activities and partly because students with limited time will make strategic decisions about the studyrelated activities that they find more or less valuable (Devlin, 2013; McInnis \& Hartley, 2002). Many teaching staff report declining lecture attendance rates (Massingham \& Herrington, 2006; Phillips et al., 2007; Shannon, 2006), and studies emerging from Australia, Canada, the United Kingdom, and the United States expose this as a “universal challenge” (Doyle, O'Brien, Tobin, \& O'Rourke, 2008; Gump, 2005; Hughes, 2005; Hunter \& Tetley, 1999; Leufer \& Cleary-Holdforth, 2010). A significant aspect of this development is that students are readily embracing new technologies, which grant them greater convenience, flexibility, and anytime/anywhere access (Fardon, 2003). This prompts critical reflection about the quality of learning that can occur when students are increasingly not present at physical locations and when physical locations and traditional, face-to-face pedagogical approaches remain dominant (Devlin, 2013b).

As Devlin (2013b) notes, opportunities for university participation and success through the use of appropriate technologies are particularly important to ensure that access to high quality learning is not restricted only to students who fit traditional notions of a tertiary student; that is, a young, full-time, recent school leaver from a middle class background with no dependents, minimal or no employment responsibilities, and few commitments outside of study, who spends a lot of time on campus. The majority of Australian higher education students do not fit this profile. 
To ensure equitable access to, and participation in, higher education, and a high quality learning experience for all students, institutions need to be increasingly flexible in their conceptions, thinking, and delivery of education, without compromising standards (Garrison \& Vaughan, 2013). Across the world, education paradigms are shifting to include, among other developments, more flexible approaches, online learning, blended learning and collaborative models of learning (Beetham \& Sharpe, 2013; Dias, Diniz, \& Hajileontiadis, 2014; Garrison \& Kanuka, 2004; Johnson et al., 2013). Outside the peer-reviewed literature, there is also growing awareness of the potential value of technology in education in Australia, particularly from industry in relation to the need to create work ready graduates. For example, the 2013 annual report from the Australian Workforce and Productivity Agency recommends promotion of the effective use of technology in teaching and learning. Reports by Norton (2012) and Ernst and Young (2012) provide similarly strong arguments for the use of technology and highlight the potential of its transformational capacity in education. These shifts are seen as the way forward and, as the results from the study (Devlin et al., 2012) reported below indicate, they are particularly significant to the success of students from LSES backgrounds.

\section{Particular characteristics of LSES students}

This paper is premised on the view that the use of technologies in university teaching is an inevitable and critical way forward for tertiary institutions operating in the digital economy. Further, the potential benefits of the use of technology for social inclusion, specifically in teaching students from LSES backgrounds, are significant. Devlin (2010) suggests that LSES students may have particular challenges to overcome in order to succeed at tertiary level (see also Thomas, 2013). Devlin (2010) argues, for example, that there is a tertiary student role that needs to be learnt and mastered, and that if a student has no familial or other experience of tertiary study, as is the case for many LSES students, the successful student role will be unfamiliar and, therefore, challenging to understand, adjust to, learn, practice, and master (see also Lawrence, 2005). McKay and Devlin (2014) propose that the tacit expectations of students and the language used within tertiary discourses may also present particular challenges. Further, Devlin (2010) suggests that having given LSES students access to tertiary education, the sector has a responsibility to articulate the successful student role and genuinely and proactively facilitate attempts by students to meet the expectations institutions have of them. It may be that technology can assist with these challenges and this responsibility.

Devlin and McKay (2011) note that LSES students often contend with financial issues that can impact significantly on their higher education experience. A study commissioned by Universities Australia found 76.6\% of students from LSES backgrounds experienced financial distress and worry about their finances. The study also found that this "worry" translated to "real, negative outcomes for them: they are around three times as likely to have had to defer because of finances at some point than are others (15.1 per cent compared with 5.2 per cent), and, most tellingly, one in four of those who worry about finances - 25.2 per cent - indicate that they regularly go without food or other necessities because they cannot afford them" (Bexley, Daroesman, Arkoudis, \& James, 2013, p. 9). Further, there is a greater chance that students from LSES backgrounds will find themselves under economic pressure to prioritise work over their education (Greenbank, 2006). As a result of balancing financial pressures, family responsibilities, and/or significant hours of employment with study, many LSES students are also under greater time constraints than other students (David et al., 2010; Murphy, 2009). Devlin et al. (2012) also note that students from LSES backgrounds are particularly "time poor". Their research shows that many LSES students in Australia are juggling employment and caring and family responsibilities alongside the demands of study. These "real, negative outcomes" (Bexley 2013, p. 9) relating to LSES students are also echoed in the international data (see OECD, 2012).

\section{The potential of technology for LSES students}

According to research, one way to ensure the relevance and quality of teaching and learning with diverse student cohorts is through the use of technology (Bullen \& James 2007; Milliken \& Barnes, 2002; O’Flaherty, Scutter, \& Albrecht 2010). As well as facilitating greater access to tertiary study, the use of technology in the learning environment can make classes more engaging and increase student commitment and performance (Kuh \& Vesper, 2001; Milliken \& Barnes, 2002; Nelson Laird \& Kuh, 2005). 
The purpose of this paper is to explore how technology might be best employed to contribute to the study experiences and outcomes of students from LSES backgrounds in the current tertiary policy context. Staff and student conceptualisations of the quality and benefits of teaching with technology from a larger study are extracted, examined, and articulated. It is hoped that these research findings will add to the body of knowledge about the experiences of LSES students at tertiary level and, in particular, contribute to understandings of why and how educational technologies in particular might be best employed in teaching and learning and student support to enhance student outcomes.

\section{Methodology}

\section{The overall approach}

The methodological approach of the research study from which the findings reported in this paper were drawn was success-focused. Noting that much understanding of the issues facing LSES students has come from research and investigation focused on the barriers to success and the problems LSES students face, the research deliberately adopted an approach focused on success (Devlin et al., 2012). As Devlin (2009) explains in relation to another equity student group, Indigenous students, "Giving prominence to a research-led focus on 'what works' in terms of ... student equity in higher education will provide evidence-based guidance for policy and practice" (pp. 1-2). She argues further that, "leveraging the experience of the many hundreds of successful ... [students], it may be possible to articulate some of the ways in which higher education success has been, and can be, achieved, despite the challenges that face... [these] students” (p. 2).

The larger research study recruited successful LSES students. For the purposes of the research, successful was defined as having completed a year of university study and re-enrolled for another year. There are substantial bodies of evidence that confirm that a successful first year is necessary as a foundation for later year success (Kift, 2009; Kift \& Nelson, 2005; Nelson, Clarke, Kift, \& Creagh, 2011). The aim in particular was to uncover aspects of these students' experiences that had helped them choose to stay at university, despite the challenges and obstacles they may have faced in the first, challenging period of their university experience. Socioeconomic status was measured using the postcode of the students' home address, and while this metric of postcode is seen as problematic (Devlin \& O'Shea, 2012), it remains the official determinant of socioeconomic status in Australia. Extending this measure, the project concentrated on three factors to determine participant eligibility in the initial screening. These were successful completion of at least one year of university, a home address with an LSES postcode, and no parents who had studied at a university.

The study also recruited successful staff. These were staff who were identified by the research team, early interviewees in the study, and others via snowball sampling as having demonstrated success in effectively teaching and/or supporting LSES students at university.

\section{Research questions}

The original study aimed to determine what helps LSES students succeed at university. Students were asked open-ended questions about what had helped them to be successful and follow-up questions specifically about the teaching, assessment, and support they had experienced while studying. The student interview questions appear below. Staff were asked to describe the approaches, strategies, and techniques they used with LSES students to enable their success. The staff interview questions also appear below. The central research question of the original study was "What works to effectively teach and support LSES students?” This paper focuses on the findings related to technology.

Questions used in student interviews

(1) What has helped you to learn while you have been a student at university?

(2) Were there any particular aspects of your experience at uni that helped you pass subjects (courses/units)?

(3) What else do you think has helped you succeed at university?

(4) Are there particular teachers or teaching styles that have been more helpful than others?

(5) What has helped you do well in assessment tasks?

(6) Are there people in your life who have been helpful? Who? How have they been helpful? 
(7) Are there aspects of your financial arrangements or circumstances that have made things easier for you to study?

(8) Were there any particular services that assisted you to succeed at uni?

(9) If you had to give an award to a person, service or thing that has helped you most as a student at university, who or what would it be?

(10) If you had to give advice to a student (from your old school/home town/suburb/area) coming to university about succeeding as you have done, what would you suggest to them?

(11) Is there anything else you'd like to tell me about how you have succeeded as a student at university?

Questions used in the staff interviews

(1) What particular strategies do you employ for teaching and/or supporting students from diverse backgrounds?

(2) Could you tell me about any resources that you use to support these teaching strategies? May we please have copies of these resources?

(3) Could you tell me about your approach to assessment?

(4) How do you design assessment to accommodate the needs of the students from diverse backgrounds?

(5) Do you do anything in particular to support LSES students?

(6) What advice would you provide for colleagues about how they could enhance their practice in teaching and supporting students from diverse backgrounds?

(7) Can you identify any particular assistance you need to enhance your teaching and/or support practices?

\section{Conceptual and theoretical framework}

In addition to the success-focused approach, the study adopted a distinctive conceptual framework developed by Devlin (2013a), which avoids adopting either a deficit conception of students from LSES backgrounds or a deficit conception of the institutions in which they study. Rather than being the primary responsibility of solely the student or the institution to change to ensure LSES student success, the study took the position that the adjustments would be most usefully conceptualised as a joint venture towards bridging sociocultural incongruity (Devlin, 2013a, pp. 1-2). The notion of sociocultural incongruence is adopted as a way of conceptualising the differences in cultural and social capital between students from LSES backgrounds and the high socioeconomic status institutions in which they study (see Bourdieu, 1986).

The first deficit conception assumes students are the problem. However, the assumption that university success is primarily the responsibility of individual students can presuppose a level playing field in relation to sociocultural and background characteristics. As Devlin et al. (2012) suggest, it can be very seductive to think that if students from LSES backgrounds are just clever enough, and/or try hard enough, or persevere enough, or believe enough in their own ability, they can engineer their success at university themselves. Devlin (2013a) maintains the tacit expectations inherent in university practices are within a sociocultural subset that is peculiar to the upper socioeconomic levels. Unless these implicit expectations are made explicit, they may operate to exclude students from LSES backgrounds who are not familiar with the norms and discourses of universities.

The second deficit conception is that institutions are the problem. Some suggest that rather than requiring students to fit the existing institutional culture, institutional cultures should be adapted to better fit the needs of an increasingly diverse student body (Zepke \& Leach, 2005). As Devlin (2013a) and Devlin et al. (2012) point out, a number of research findings point to the "fault" of institutions. For example, Billingham (2009) suggests that there are situational and dispositional barriers created by institutional inflexibility. Tett (2004, p. 252) says "the role of the educational institution itself in creating and perpetuating inequalities” should be taken into account. Bamber and Tett (2001) claim it is unfair to expect the burden of change to fall solely on the students and that institutions should make changes, and James, Krause, and Jenkins (2010) argue universities should make changes in terms of heralding the expectations they have of students. However, Devlin (2010) argues that to genuinely contribute to the 
success and achievement of non-traditional students, universities need to do much more than to spell out their expectations for student involvement in learning.

The sociocultural conception on which the larger study was based is that instead of blaming students or institutions, the idea that incongruence must be bridged is adopted. The notion of "sociocultural incongruence" (Devlin, 2013a) is one that describes the circumstances in which students from LSES backgrounds attempt to engage with the particular sociocultural discourses, tacit expectations and norms of higher education. Murphy's (2009) UK study of factors affecting the progress, achievement and outcomes of new students to a particular degree program found a number of characteristics specific to the institution and to individual students that promote progression and achievement. These factors enable the incongruence between students and institutions to be bridged. This conceptual framework underpinned the study.

Further, the study adopted a theoretical approach drawn from constructivism (Bruner, 1996), transition pedagogy (Kift, 2009; Kift \& Nelson, 2005) and inclusive pedagogy (Waterfield \& West, 2006), as well as on conceptual work undertaken by Warren (2002) in integrated curriculum design. The study also adopted Hockings' (2010) point that rather than assuming that non-traditional students have special needs that require attention outside the curriculum in adjunct programs, integrated curriculum design targets all students and assumes that they bring to the learning environment varying resources in the cognitive, linguistic, knowledge and cultural domains. It was assumed that these students draw on what they bring to the higher education context and need to be guided to "develop the critical and communicative skills and conceptual repertoires that will enable them to deal with academic tasks” (Warren, 2002, p. 87).

\section{Data collection}

Data for the larger research study was collected from four major sources:

(1) a review of peer reviewed and other significant literature in the broad area of the experience of students from LSES backgrounds in higher education;

(2) interviews with 89 students who were from LSES backgrounds and in the first generation of their family to attend university;

(3) interviews with 26 staff known for their expertise in teaching and/or supporting students from LSES backgrounds at university; and

(4) an environmental scan of effective policy, programs and practice in teaching and/or supporting students from LSES status backgrounds across Australia.

A total of 17 of the 39 Australian universities were involved in providing data for the research. These represented universities with campuses in Victoria, Queensland, Western Australia, Tasmania, New South Wales, South Australia, and the Australian Capital Territory. The sample included representation from the Australian Technology Network, the Group of Eight, dual sector universities, regional universities, unaligned universities, and post-Dawkins universities.

This paper draws directly on data collected from the second and third sources - the interviews with students and staff. These 115 interviews, which were either face-to-face or via telephone, were undertaken at universities, and particular campuses of universities, where there are high proportions of students from LSES backgrounds; that is, at sites where existing experience and expertise within the Australian context was already concentrated. The rationale for this approach relates to the successfocused nature of the research. Students were interviewed individually and their views on what works in terms of facilitating their success were sought. Students were assigned individual codes to protect their anonymity (i.e., STUDENT_XX, abbreviated herein as STU_XX). Staff were also interviewed individually to determine their views on what works in teaching and supporting LSES students. Staff interviews were similarly coded to protect interviewee anonymity (i.e., COLLEAGUE_XX, abbreviated herein as COL_XX).

Findings from the study that related to the use of technology for effective teaching and support for LSES students were extracted. The data from interviews with 89 students and 26 staff in the larger study were re-examined with a focus on responses that included references to technology. The literature review provided a context for interpreting the interview data but the findings from the literature review and the 
scan are not directly reported in this paper. This means that the conclusions here are informed by a review of peer-reviewed and other significant published literature; and by data on almost 30 effective programs and initiatives for LSES students across Australia.

All interviews were recorded and then transcribed, and the data was subsequently analysed using NVivo 9. A thematic analysis of the data was undertaken, and initial outcomes underwent rigorous inter-coder reliability and validity checks among a team of experienced researchers. Adopting a two-stage approach, an initial thematic analysis of the data was undertaken by two experienced researchers to ensure reliability of the findings. The next step entailed audit checks of the coding and analysis by two senior researchers on the team. Throughout the process, inter-coder review and recursive examination of analysed data ensured both coding and coder reliability.

The findings were synthesised with reference to the conceptual framework and a set of principles that emerged from an earlier stage of the project. Details on the larger project can be found in Devlin et al. (2012). Interview data was re-examined for this paper for themes related to teaching and learning with technology.

\section{Results}

One of the broad themes that emerged from the findings of the larger study was that flexibility, variety and choice for students were important components of facilitating success. The significance of flexibility is a finding echoed in the literature and prior studies (Devlin et al., 2012; Gale et al., 2010). Within that broad theme, teaching with technology was seen as one important way through which students from LSES backgrounds could be offered the flexibility with place and timing of study they often require.

Both staff and students interviewed commented on the important role of technology in enhancing the higher education experience for LSES students. A total of 52 comments from students and 13 comments from staff were coded under the sub-theme of teaching with technology.

Within this sub-theme, four principles were evident in the data:

(1) Using a range of resources and media

(2) Facilitating interactive and connected learning

(3) Enabling personalised learning

(4) Assuring high academic standards.

Examples of each principle from the interview data are provided in turn below. Although quantitative data was not garnered on these points given that this was a qualitative study, only those themes most frequently cited by respondents are reported here.

\section{Use of a range of resources and media}

When asked about what worked in terms of facilitating success for students from LSES backgrounds, staff offered the following sorts of comments about the importance of using a range of resources:

So the resources that I would use in a lecture situation would be references to any kind of popular cultural things that are happening, so you use YouTube, or I use a lot of photos or images in my teaching that represent diversity or the experiences to illustrate any of the kinds of content that I teach [COL_008].

The uploading of lectures with the PowerPoint slides attached to them, I think, has been a big step. I've had lots of students say that they find that much more involving than reading stuff. Hearing the voice and then seeing the slides at the same time ... I think the impact of that is still quite strong [COL_002].

Although these are not examples of particularly unusual or innovative uses of technology, the first example indicates the importance of using multimedia and of choosing formats and content that represent the students' experience. This reduces the risk of students from LSES backgrounds feeling alienated from 
the content they are being taught because it is unfamiliar and they, therefore, cannot relate to it. The second example points to the need to engage students through technology and to the fact that technological savviness on the part of staff is not necessarily required to do so. The addition of sound to vision does not usually require significant up-skilling by staff but can have a very positive effect on student engagement with learning material.

A student points to the benefits of being engaged by and enjoying learning offered through technology and the opportunity to choose the formats that best suit his/her circumstances:

I think the most important thing is having a large range of resources available ... to have audio ... podcast and ... video ... I particularly enjoy learning by listening to things. So to have those extra ... resources which are ... more catered to me and I can choose to use them. I found that that's beneficial for me [STU_045].

There are many ways in which technology can be used to effectively teach students from LSES backgrounds. The results indicate that the principle of using a range of technological resources should underpin decisions about which technologies to use and about how to use them.

\section{Interactive and connected learning}

Students were particularly emphatic about the importance of their learning being interactive. Technology was seen as a useful tool in achieving this and the qualitative data reveals that such interactivity ultimately made students feel more connected:

All the online technology was fantastic and the eLive sessions, I really enjoyed them because you connected with people and the lecturer about the topic [STU_001].

This interactivity was seen as essential for students who were new to the academic world. In the learning and teaching space, students commented on the need for teachers to have an active online presence in order to engage students. One student summarised typical comments:

The online interactive ... presentations ... They’ve been really good_... I felt that teachers who wanted to use that technology have been probably a little bit more effective [STU_051].

Both staff and students highlighted interactivity as having played a significant role in the success of those students who were studying off campus or undertaking online units. As one student said:

I found the subjects where the teachers are far more interactive on the forum and where there was a chat room for the subject, were easy to feel a part of and easier to feel connected and therefore assisted with the learning [STU_051].

\section{Personalised learning}

The capacity of technology to personalise the learning experience was seen by both staff and students alike as potentially beneficial to student success. The personalised experience was seen to empower students by enabling them to plan and organise their studies to fit in with their schedules and competing demands. One student articulated the benefits of using technology to plan and organise their study around other commitments and to enhance their learning:

That whole online concept, where you can email your lecturers, and you nearly feel like you've got 24-hour access to your learning material [is helpful]. There's even learning material put on a couple of weeks in advance, so if I'm on task ... I can look ahead and ... You can see what's coming, rather than just being blind, and try ... to prepare yourself for the semester. I feel like I can lay everything out, I know when my exams are, I know when my assignments are due right from the very beginning, so I can plan everything around the three kids [STU_054]. 
The potential for a personalised learning experience was also seen to allow students to repeat and review at their own pace. As one student commented:

The [lecture] recordings have been really popular, even with sort of mature-aged students ... [who] you would think wouldn't be as keen on technology. We do get a lot of feedback, good feedback that it just provides flexibility, and they can listen as many times as they want [COL_030].

Students pointed to the importance of this in their busy lives, where they were often juggling multiple responsibilities and being able to learn in their own time and at their own pace was critical to their academic success. When asked what most helped them succeed in their studies, typical comments included:

The recording of the lectures ... for exam preparation I will re-listen, especially with statistics which is ... so much to learn in a two hour lecture ... But I would go over them all before an exam so I think that [helped me] [STU_095]

I have to travel a bit further than most people so if I just have a really short day or something it's really inconvenient so sometimes I just go online. The online module[,] ... the lectures ... being recorded ... [and the] online unit ... [are] very useful for me. That's what's made uni a bit easier [STU_008].

\section{High academic standards}

One major question that the implementation of flexibility, variety and choice raises is around the protection of high academic standards. Staff interviewed were united on the need to maintain academic standards and went to great pains to point out that the common assumptions made about LSES students and standards were erroneous and unfounded. As several staff pointed out:

I've found that the low SES kids that we've got here are just very determined. They're very smart and determined people and it takes them a couple of years to nut out the system but if you are halfway welcoming, they can do it very quickly [COL_007].

We take students who are low socioeconomic and first in their family to go university ... and last year and the year before that we had 25 per cent of them graduated with distinction [COL_023].

I had someone [from a LSES background] who got high distinctions, who came to see me to be better [COL_001].

One staff member offered advice in relation to standards to those teaching and supporting LSES students:

I think the first thing I would say is don’t make assumptions about the students. Even within any kind of category that you'd want to give a student a label, there is a diversity and wealth of experiences within that and what I worry about is that if you have the assumption that students are a particular way, that's how you teach them and I think you should always teach students with the expectation that they can excel and that they are capable and have capacity [COL_008].

Finally, one staff member commented on the assumed undermining of high standards that comes with a more focused approach to learning and teaching:

It's not about dumbing things down ... it's [about] clarifying the expectations [COL_004].

The findings indicated that careful and thoughtful use of technology offers students the option to study at times and in places that best suit them as they balance a multitude of competing demands, including paid employment and family commitments alongside their study commitments (Devlin et al., 2012). 


\section{Discussion}

This section outlines the significance of the findings reported in this paper, the potential implications for practice and policy, the limitations of the study and some suggested directions for future research.

\section{Significance of the findings}

This paper advances knowledge in a little researched area - the role of technology in facilitating the success of students from LSES backgrounds in Australian higher education. It shows that within the theme of providing flexibility, variety and choice for students from LSES backgrounds who are often time poor, using a range of resources and media, facilitating interactive and connected learning, enabling personalised learning and assuring high academic standards are important contributors to student success.

The paper also contributes to thinking about the criteria of effective teaching in a changing higher education context. Following a comprehensive examination of what constitutes teaching effectiveness in higher education, Devlin and Samarawickrema (2010) conclude that the collective understanding of competent, professional and effective teaching must continually evolve in order to accurately reflect and respond to the contexts in which teaching and learning take place. In what they view as "a changed, and changing, context” (p. 111), teachers need to be willing to embrace changes to their roles and to the understanding of what effectiveness in those roles mean.

This paper suggests that there is evidence to warrant additional criteria of effective teaching. For example, additional criteria that recognise the particular and challenging demands on teachers in "applying enduring pedagogies by understanding and capitalizing on emerging technologies; moving with technological innovations to suit needs of new learner generations; and adapting to changing conceptions of flexibility” (Devlin \& Samarawickrema, 2010, p. 121) might be considered.

\section{Implications for practice and policy}

A major implication for practice and policy from the findings reported here lies in the changing role of educators. Inherent in the use of technology in teaching, there is less emphasis on the notion of the educator as the sage on the stage and more interest in the idea of him/her as the guide on the side. As Devlin (2013b) notes, in addition to focusing on the content of their disciplines and/or professional areas, university teachers must now also embrace personalised and collaborative learning alongside didactic methods of teaching and connect students to each other and to staff using the most appropriate forums and tools for their learning objectives.

In an age of technology ubiquity, a greater focus on the use of technology to effectively teach and support LSES students is likely to be beneficial to the ever-increasing number studying online and in blended forms in Australia and beyond. This paper thus has significance for all policy makers and leaders, educators and students in the technology-enabled higher education environment. The findings discussed in this paper indicate that technology can indeed assist with the challenges often faced by students from LSES backgrounds and the responsibilities of institutions and educators in enabling their success. Drawing on the words of one of the educators to participate in the study from which this paper is drawn:

Definitely take advantage of technology and celestial media. The world has changed. [COL_030]

Further, as teaching with technology becomes more commonplace in higher education, teaching and support staff will need to continually review their use of technology in order to "ensure it is inclusive and that it supports a wide range of learning preferences and individual circumstances” (Devlin et al. 2012, p. 10). Institutional policy makers and leaders will need to "consider the availability of appropriate technology and connectivity for LSES students" as well as "ensuring policy and other decisions do not exclude LSES students from learning and other opportunities” (Devlin et al., 2012, p. 12). 
University teaching has many forms and meanings. As Devlin (2013b) notes, the academic role is being unbundled across the world. Teaching specialists of various kinds are emerging and "traditional so-called 'content experts' now work collaboratively with learning and/or educational designers, eLearning specialists, curriculum consultants, language and academic skills experts, library staff, information technology staff, space designers and others to create and deliver curriculum and learning environments and experiences' (p. 3). It is certainly timely to rethink the teacher's role in universities alongside reward and recognition mechanisms for teaching and examine the institutional policies that underpin all of this. Critical questions might include:

- How should institutions orient and induct new staff into teaching with technology?

- What professional development for ongoing enhancement is appropriate?

- Where and how should support for staff using technology in learning and teaching be provided?

- To what extent should innovation in teaching using technology feature in criteria for awards and promotion?

\section{Limitations of the study}

In terms of limitations, the data drawn on in this paper emerged from a larger study about what helps students from LSES backgrounds achieve academic success. The larger study was not specifically focused on the role of technology in LSES student success, and important aspects of technology and how it impacts the experiences and learning of students from LSES backgrounds may, therefore, have been overlooked. Further, while the sample was robust, it was not particularly large, and future research would include a larger sample and a sharper focus on LSES students and their relationship to, views about and experiences of, technology in learning.

\section{Conclusion}

Technology is transforming higher education as it increasingly becomes a natural part of the lives of both educators and students. Recent studies point to the transformational capabilities of technology to improve the learning and success of students from diverse backgrounds, particularly those from LSES backgrounds. The research reported in this paper indicates that teaching with technology provides LSES students with the flexibility and options they require in order to access and participate successfully in tertiary study. Further, the research found that the careful and thoughtful use of technology can significantly enhance the higher education experiences and outcomes for these students.

The findings on effective teaching and support of LSES students through technology outlined in this paper will be of value to the Australian higher education sector in their efforts with LSES students. Devlin et al. (2012, p. 67) maintain:

This would ensure that the significant effort being made by the government and institutions to build aspirations and attract more LSES students to higher education is not wasted through unnecessary and avoidable attrition once those students reach university. It is critical to understand and learn from 'what works' in ensuring the success of LSES students in Australian higher education. Such understanding is particularly important in a context where resources are shrinking and there is a 'growing list of change forces in the environment that are challenging universities with ferocious intensity' (Fullan and Scott, 2009, p. 1). As these change forces continue to intensify, further research will be necessary to ensure that teaching and supporting LSES students evolves and develops to accommodate the changing external and internal contexts in which it takes place.

\section{Acknowledgements}

The study on which this paper was based was funded by the Australian Commonwealth Office for Learning and Teaching (OLT) and led by Deakin University. The views expressed in this paper are not necessarily those of the government, the OLT, or Deakin University. We gratefully acknowledge the contributions of our project team colleagues to the research. 


\section{References}

Austrade. (2012). More than MOOCS: Opportunities arising from disruptive technologies in education. Canberra: Australian Government. Retrieved from

http://www.austrade.gov.au/Australian/Education/News/Reports/More-than-MOOCs--Opportunitiesarising-from-disruptive-technologies-in-education

Australian Work and Productivity Agency. (2013). Annual Report 2012-13. Canberra: Australian Government. Retrieved from https://infrastructure.gov.au/department/annual_report/2012_2013/files/INFRASTRUCTURE_AR_20 12_13_FULL_DOCUMENT.pdf

Bamber, J., \& Tett, L. (2001). Ensuring integrative learning experiences for non-traditional students in higher education. Widening Participation and Lifelong Learning, 3(1), 8-16. doi:10.1080/01580379950143519

Barrington, E. (2004). Teaching to student diversity in higher education: How multiple intelligence theory can help. Teaching in Higher Education, 9(4), 421-434. doi:10.1080/1356251042000252363

Beetham, H., \& Sharpe, R. (Eds.) (2013). Rethinking pedagogy for a digital age: Designing for 21st century learning. London: Routledge.

Bennett, S., Maton, K., \& Kervin, L. (2008). The 'digital natives’ debate: A critical review of the evidence. British Journal of Educational Technology, 39, 775-786. doi:10.1111/j.14678535.2007.00793.x

Bexley, E. (2013, July). University student finances in 2012. Melbourne: University of Melbourne, Centre for the Study of Higher Education. Retrieved from http://apo.org.au/node/34869

Bexley, E., Daroesman, S., Arkoudis, S., \& James, R. (2013). University student finances in 2012: A study of the financial circumstances of domestic and international students in Australia's universities. Melbourne, Australia: Universities Australia.

Billingham, S. (2009, June). Diversity, inclusion, and the transforming student experience. Paper presented at the 18th European Access Network Annual International Conference, York. Retrieved from http://www.ean-edu.org/assets/stuart-billingham.ppt

Bourdieu, P. (1986). The forms of capital. In J. G. Richardson (Ed.), Handbook of theory and research for the sociology of education (pp. 241-258). New York, NY: Greenwood Press.

Bruner, J. (1996). The culture of education. Cambridge, MA: Harvard University Press.

Bullen, M., \& James, D. P. (Eds.) (2007). Making the transition to e-learning: Strategies and issues. Hershey, PA: Information Science Publishers. doi:10.4018/978-1-59140-950-2

Coaldrake, P. (2001). Responding to changing student expectations. Higher Education Management, 12(2), 75-92. doi:10.1787/hemp-v13-2-en

Condie, R., Munro, B., Seagraves, L., \& Kenesson, S. (2007). The impact of ICT in schools: A landscape review. London: British Educational Communications and Technology Agency (BECTA). Retrieved from http://www.teindia.nic.in/e9-tm/Files/ICT_Documents/ImpactICT_Becta.pdf

Cox, M., Abbott, C., Webb, M., Blakely, B., Beauchamp, T., \& Rhodes, V. (2004). A review of the research literature relating to ICT and attainment. London: British Educational Communications Technology Agency (BECTA). Retrieved from. http://dera.ioe.ac.uk/1600/1/becta_2003_attainmentreview_queensprinter.pdf

David, M., Crozier, G., Hayward, G., Ertl, H., Williams, J., \& Hockings, C. (2010). Institutional practices and pedagogies for social diversity. In M. David (Ed.), Improving learning by widening participation in higher education (pp. 180-201). London: Routledge.

Davies, S., \& Pittard, V. (2008). Harnessing technology review 2008: The role of technology and its impact on education (Full Report). London: British Educational Communications and Technology Agency (BECTA). Retrieved from http://dera.ioe.ac.uk/1423/

Devlin, M. (2009). Indigenous higher education student equity: Focusing on what works. Australian Journal of Indigenous Education, 38, 1-7. Retrieved from http://www.academia.edu/794751/Indigenous_higher_education_student_equity_focusing_on_what $\underline{\text { works }}$

Devlin, M. (2010, June). Non-traditional university student achievement: Theory, policy and practice in Australia. Keynote address at the 13th Pacific Rim First Year in Higher Education Conference, Adelaide, Australia.

Devlin, M. (2013a). Bridging socio-cultural incongruity: Conceptualising the success of students from low socio-economic status backgrounds in Australian higher education. Studies in Higher Education, 38(6), 939-949. doi:10.1080/03075079.2011.613991 
Devlin, M. (2013b). eLearning Vision. Ballarat: Federation University Australia. Retrieved from http://federation.edu.au/_data/assets/pdf_file/0020/159122/FedUni_eVision2014.pdf

Devlin, M., Kift, S., Nelson, K., Smith, L., \& McKay, J. (2012). Effective teaching and support of students from low socioeconomic status backgrounds: Resources for Australian higher education (Final Report). Sydney: Office for Learning and Teaching, Commonwealth of Australia. Retrieved from http://www.lowses.edu.au/assets/ALTC\%20LSES\%20Final\%20Report\%202012.pdf

Devlin, M., \& McKay, J. (2011). Inclusive teaching and support of university students from low socioeconomic status backgrounds (Discussion paper). Melbourne: Deakin University. Retrieved from http://lowses.edu.au/assets/lses-discussion-paper-devlin-mckay.pdf

Devlin, M., \& O’Shea, H. (2012). Effective university teaching: Views of Australian university students from low socio-economic status backgrounds. Teaching in Higher Education, 17(4), 385-397. doi:10.1080/13562517.2011.641006

Devlin, M., \& Samarawickrema, G. (2010). The criteria of effective teaching in a changing higher education context. Higher Education Research \& Development, 29(2), 111-124. doi:10.1080/07294360903244398

Dias, S. B., Diniz, J. A., \& Hadjileontiadis, L. J. (2014). E-learning exequibility in the information and knowledge society. In S. B. Dias, J. A. Diniz, \& L. J. Hadjileontiadis (Eds.), Towards an intelligent learning management system under blended learning (pp. 3-19). Basel: Springer. doi:10.1007/978-3319-02078-5_1

Dobbins, K. (2009). Feeding innovation with learning lunches: Contextualising academic innovation in higher education. Journal of Further and Higher Education, 33(4), 411-422. doi:10.1080/03098770903272495

Doyle, L., O'Brien, F., Tobin, G., \& O'Rourke, F. (2008). An evaluation of an attendance monitoring system for undergraduate nursing students. Nurse Education in Practice, 8, 129-139. doi:10.1016/j.nepr.2007.09.007

Ernst \& Young. (2012). University of the future: A thousand year old industry on the cusp of profound change. Sydney: Author.

Fardon, M. (2003). Internet streaming of lectures: A matter of style. Retrieved from http://citeseerx.ist.psu.edu/viewdoc/download?doi=10.1.1.509.9377\&rep=rep1\&type=pdf

Friedrich, R., Le Merle, M., Peterson, M., \& Koster, A. (2010). The rise of Generation C: Implications for the world of 2020. London: Booz \& Co. Retrieved from http://lowses.edu.au/assets/lsesdiscussion-paper-devlin-mckay.pdf

Gale, T., Sellar, S., Parker, S., Hattam, R., Comber, B., Tranter, D., \& Bills, D. (2010). Interventions early in school as a means to improve higher education outcomes for disadvantaged (particularly low SES) students. Canberra: Commonwealth of Australia. Retrieved from http://dro.deakin.edu.au/eserv/DU:30040776/gale-interventions-componenta-2010.pdf

Garrison, D. R., \& Kanuka, H. (2004). Blended learning: Uncovering its transformative potential in higher education. The Internet and Higher Education, 7(2), 95-105. doi:10.1016/j.iheduc.2004.02.001

Garrison, D. R., \& Vaughan, N. D. (2013). Institutional change and leadership associated with blended learning innovation: Two case studies. The Internet and Higher Education, 18, 24-28. doi:10.1016/j.iheduc.2012.09.001

Geer, R., \& Sweeney, T. (2012). Students' voices about learning with technology. Journal of Social Sciences, 8(2), 294-303. doi:10.3844/jssp.2012.294.303

Greenbank, P. (2006). Institutional widening participation policy in higher education: Dealing with the issue of social class. Widening Participation and Lifelong Learning, 8(1), 199-215. doi:10.1080/13596740600769123

Gump, S. (2005). The cost of cutting class: Attendance as a predictor of success. College Teaching, 53(1), 21-26. doi:10.3200/CTCH.53.1.21-26

Hockings, C. (2010). Inclusive teaching and learning in higher education: A synthesis of research. York: Higher Education Academy. Retrieved from https://www.heacademy.ac.uk/sites/default/files/inclusive teaching and learning in he 1.doc

Hughes, S. J. (2005). Student attendance during college-based lectures: A pilot study. Nursing Standard, 19(47), 41-49. doi:10.7748/ns2005.08.19.47.41.c3925

Hunter, S., \& Tetley, J. (1999). Lectures: Why don’t students attend? Why do students attend? In Proceedings of the 22nd HERDSA Annual International Conference (pp. 1-8). Milperra: Higher Education Research and Development Society of Australia. Retrieved from http://www.herdsa.org.au/wp-content/uploads/conference/1999/pdf/Hunter.PDF 
James, R., Krause, K., \& Jenkins, C. 2010. The first year experience in Australian universities: Findings from 1994 to 2009. Melbourne: University of Melbourne, Centre for the Study of Higher Education. Retrieved from http://www.cshe.unimelb.edu.au/research/experience/docs/FYE_Report_1994_to_2009.pdf

Johnson, L., Adams Becker, S., Cummins, M., Estrada, V., Freeman, A., \& Ludgate, H. (2013). NMC Horizon Report: 2013 Higher Education Edition. Austin, TX: The New Media Consortium.

Jukes, I., \& Dosaj, A. (2006, September). Understanding digital children (DKs): Teaching and learning in the new digital landscape. Paper presented at the Mass Teacher Lecture, Singapore. Retrieved from http://jayneturner.pbworks.com/w/file/fetch/28960601/Jukes\%20\%20Understanding\%20Digital\%20Kids.pdf

Kift, S. (2009). Articulating a transition curriculum to scaffold and to enhance the first year student experience in Australian higher education (Final Report for ALTC Senior Fellowship Program). Sydney: Australian Learning and Teaching Council. Retrieved from http://www.olt.gov.au/system/files/resources/Kift_ALTC_Senior_Fellowship_Report_Sep_09.pdf

Kift, S., \& Nelson, K. (2005). Beyond curriculum reform: Embedding the transition experience. In A. Brew \& C. Asmar (Eds.), Higher Education in a Changing World. Proceedings of the 28th HERDSA Annual Conference (pp. 225-235). Milperra: Higher Education Research and Development Society of Australia.

Kuh, G. D, Vesper, N. (2001). Do computers enhance or detract from student learning? Research in Higher Education, 42(1), 87-102. Retrieved from http://www.jstor.org/stable/40196421

Lawrence, J. (2005). Re-conceptualising attrition and retention: Integrating theoretical, research and student perspectives. Studies in Learning, Evaluation, Innovation and Development, 2(3), 16-33. Retrieved from http://shiftwork.cqu.edu.au/include/getdoc.php?id=339\&article=85\&mode=pdf

Leufer, T., \& Cleary-Holdforth, J. (2010). Reflections on the experience of mandating lecture attendance in one school of nursing in the Republic of Ireland. AISHE-J: The All Ireland Journal of Teaching and Learning in Higher Education, 2(1), 18.1-18.14. Retrieved from http://ojs.aishe.org/aishe/index.php/aishe-j/article/viewFile/18/17

Massingham, P., \& Herrington, T. (2006). Does attendance matter? An examination of student attitudes, participation, performance and attendance. Journal of University Teaching and Learning, Practice, 3(2), 3. Retrieved from http://ro.uow.edu.au/jutlp/vol3/iss2/3

McInnis, C., \& Hartley, R. (2002). Managing study and work: The impact of full-time study and paid work on the undergraduate experience in Australian universities. Canberra: Department of Education, Science and Training, Commonwealth of Australia. Retrieved from https://cshe.unimelb.edu.au/research/equity/docs/eip02_6.pdf

McKay, J., \& Devlin, M. (2014). 'Uni has a different language ... to the real world': Demystifying academic culture and discourse for students from low socioeconomic backgrounds. Higher Education Research \& Development, 33(5), 949-961. doi:10.1080/07294360.2014.890570

Milliken, J., \& Barnes, L.P. (2002). Teaching and technology in higher education: student perceptions and personal reflections. Computers and Education, 39, 223-235. doi:10.1016/S0360-1315(02)000428

Murphy, B. (2009). Great expectations? Progression and achievement of less traditional entrants to higher education. Widening Participation and Lifelong Learning, 11(2), 4-14.

Nelson, K., Clarke, J., Kift, S., \& Creagh, T. (2011). Trends in policies and practices in the Australasian First Year Experience literature 2000-2010 (The First Year in Higher Education Research Series on Evidence-based Practice No. 1). Brisbane: Queensland University of Technology. Retrieved from https://www.itl.usyd.edu.au/projects/transition/Literature\%20Review.pdf

Nelson Laird, T. F., \& Kuh, G. D. (2005). Student experiences with information technology and their relationship to other aspects of student engagement. Research in Higher Education, 46(2), 211-233. doi:10.1007/s11162-004-1600-y

Northedge, A. (2002). Organizing excursions into specialist discourse communities: A sociocultural account of university teaching. In G. Wells \& G. Claxton (Eds.), Learning for life in the 21st century: Sociocultural perspectives on the future of education (pp. 252-264). Oxford: Blackwell. doi:10.1002/9780470753545.ch19

Norton, A. (2012). Mapping Australian higher education. Melbourne: Grattan Institute. Retrieved from http://grattan.edu.au/wp-content/uploads/2014/10/816-mapping-higher-education-20142.pdf

OECD. (2012). Equity and quality in education: Supporting disadvantaged students and schools. Paris: Author. doi:10.1787/9789264130852-en 
O’Flaherty, J., Scutter, S., \& Albrecht, T. (2010). How Podcasts of Lectures are used by Diverse Groups of Students. In M. Devlin, J. Nagy, \& A. Lichtenberg (Eds.), Research and Development in Higher Education: Reshaping Higher Education (33, pp. 529-539). Melbourne: Milperra: Higher Education Research and Development Society of Australia. Retrieved from http://www.herdsa.org.au/wpcontent/uploads/conference/2010/papers/HERDSA2010_O'Flaherty_J.pdf

Palfrey, J. G., \& Gasser, U. (2013). Born digital: Understanding the first generation of digital natives. New York, NY: Basic Books.

Phillips, R., Gosper, M., McNeill, M., Woo, K., Preston, G., \& Green, D. (2007). Staff and student perspectives on web-based lecture technologies: Insights into the great divide. In R. Atkinson, C. McBeath, A. Soong Swee Kit, \& C. Cheers (Eds.), ICT: Providing choices for learners and learning. Proceedings ascilite Singapore 2007 (pp. 854-864). Singapore: ASCILITE \& Nanyang Technological University. Retrieved from http://www.ascilite.org.au/conferences/singapore07/procs/phillips.pdf

Prensky, M. (2001). Digital natives, digital immigrants part 1. On the Horizon, 9(5), 1-6. doi:10.1108/10748120110424816

Prensky, M., (2005). Listen to the natives. Educational Leadership, 63(4), 8-13. Retrieved from http://www.ascd.org/ASCD/pdf/journals/ed_lead/el200512_prensky.pdf

Roberts, S. (2011). Traditional practice for non-traditional students? Examining the role of pedagogy in higher education retention. Journal of Further and Higher Education, 35(2), 182-199. doi:10.1080/0309877X.2010.540320

Shannon, S. J. (2006). Why don't students attend lectures and what can be done about it through using iPod nanos? In L. Markauskaite, P. Goodyear, \& P. Reimann (Eds.), Who’s learning? Whose technology? (pp. 753-756), Sydney: ASCILITE. Retrieved from http://www.ascilite.org.au/conferences/sydney06/proceeding/pdf_papers/p28.pdf

Tanner, L. (2011, October 26). Universities must adapt or die in the e-learning world. The Australian. Retrieved from http://www.theaustralian.com.au/higher-education/universities-must-adapt-or-die-inthe-e-learning-world/story-e6frgcjx-1226176625274

Tett, L. (2004). Mature working-class students in an 'elite' university: Discourses of risk, choice and exclusion. Studies in the Education of Adults, 36(2), 252-264. Retrieved from ERIC database. (EJ759737)

Thomas, G. (2013). Closing the policy-practice gap for low-SES students in higher education: the pedagogical challenge. Higher Education Research \& Development, 33(4), 1-14. doi:10.1080/07294360.2013.863846

Toohey, S. (1999). Designing courses for higher education. Philadelphia, PN: SHRHE \& Open University Press.

Warren, D. (2002). Curriculum design in a context of widening participation in higher education. Arts and Humanities in Higher Education, 1(1), 85-99. doi:10.1177/1474022202001001007

Waterfield, J., \& West, B. (2006). Inclusive assessment in higher education: A resource for change. Devon: University of Plymouth \& South West Academic Network for Disability Support (SWANDS). Retrieved from https://www.plymouth.ac.uk/uploads/production/document/path/3/3026/Space_toolkit.pdf

Zepke, N., \& Leach, L. (2005). Integration and adaptation: Approaches to the student retention and achievement puzzle. Active Learning in Higher Education, 6(1), 46-59. doi:10.1177/1469787405049946

Corresponding author: Jade McKay, jade.mckay@deakin.edu.au

Australasian Journal of Educational Technology (c) 2016.

Please cite as: Devlin, M., \& McKay, J. (2016). Teaching students using technology: Facilitating success for students from low socioeconomic status backgrounds in Australian universities. Australasian Journal of Educational Technology, 32(1), 92-106. 